\title{
The Social Phobia and Anxiety Inventory: First Results of the Reliability and Structural Validity in Chilean Adolescents"
}

El inventario de fobia social y ansiedad: primeros resultados de confiabilidad y validez estructural en adolescentes chilenos

Recibido: mayo 27 de 2009 | Revisado: agosto 20 de 2009 | Aceptado: septiembre 2 de 2009

\author{
José Olivares ** \\ Universidad de Murcia, España \\ PABLO Vera-VILLARROEL ${ }^{* *}$ \\ Universidad de Santiago de Chile, Chile \\ ANA I. ROSA-ALCÁZAR \\ Universidad de Murcia, España \\ WALTER KUHNE \\ Universidad de Santiago de Chile, Chile \\ LUIS MONTESINOS \\ Montclair State University, USA \\ José ANTONIO LÓPEZ-PINA \\ Universidad de Murcia, España
}

* Artículo de investigación en psicometría.

*** Postal address: José Olivares-Rodríguez, Faculty of Psychology, Department of Personality, Evaluation, and Treatments, Campus of Espinardo, P.O. Box 4021, 30100-Murcia, Spain.

Correo electrónico: jorelx@um.es

**** Escuela de Psicología. Av. Ecuador 3650, 3 piso. Santiago-Chile.

Correo electrónico: pablo.vera@usaeh.cl

\section{RESUMEN}

En este reporte se evaluaron la confiabilidad y la validez estructural de la versión Chilena del Inventario de Fobia Social y Ansiedad (SPAI, Turner, Beidel, Dancu \& Stanley, 1989) con una muestra no clínica de 1040 adolescentes Chilenos (edades entre 13 y 18 años). El análisis de validez estructural indicó la existencia de dos subescalas claramente diferenciadas (Fobia social y Agorafobia) que explican $43.4 \%$ de la varianza. Los coeficientes alfa fueron muy altos en ambas subescalas. A pesar de encontrar diferencias significativas para sexo en ambas escalas, el tamaño del efecto fue pequeño. Por otro lado, la variable edad fue significativa en la fobia social pero no en la agorafobia, con pequeño tamaño del efecto. En general los resultados ofrecen evidencia empírica que apoya la confiabilidad y la validez de la versión Chilena del Inventario de Fobia social y Ansiedad.

Palabras claves autores

Fobia social, agorafobia, confiabilidad, análisis factorial.

Palabras claves descriptor

Análisis factorial, fobia social, agorafobia.

\section{A B S T R A C T}

In this report we examined the reliability and structural validity of the Chilean version of the Social Phobia and Anxiety Inventory, SPAI, (Turner, Beidel, Dancu \& Stanley, 1989), using a sample of 1040 non clinical Chilean adolescents (range of age between 13 and 18 years). The structural validity analysis indicated the existence of two, clearly differentiated, subscales (Social Phobia and Agoraphobia) that explained $43.4 \%$ of the variance. The alpha reliability coefficients were very high in each one of the subscales. In spite of finding significant differences, for sex in both scales, the effect size was small. On the other hand, the age variable was significant in the social phobia scale but not in the agoraphobia one, but again the effect size was small. In general the results offer empirical evidence in support of the reliability and validity of the Chilean version of the Social Phobia and Anxiety Inventory.

Key words authors

Social Phobia, Agoraphobia, Reliability, Factor Analysis.

Key words plus

Factor Analysis, Social Phobia, Agoraphobia. 
Social phobia is characterized by a persistent and conspicuous fear of social situations or public performances. Prevalence rates oscillates between $3 \%$ and $13 \%$ (APA, 2000), making it the most frequent anxiety disorder found in clinical and community samples (Fairbrother, 2002; Scholling \& Emmelkamp, 1996) and the psychological disorder diagnosed after major depression and alcohol consumption and dependency (Ameringen, Manzini \& Farvolden, 2003).

Among the effects of this disorder in children \& adolescents are low academic performance, with its consequent risk of school drop out (Beidel \& Turner, 2005), the development of other anxiety or mood disorders (Essau, Conradt \& Petermann, 1999; Ingram, Ramel, Chavira \& Scher, 2001; Olivares \& García-López, 2001) and the increase of vulnerability for starting consumption of toxic substances (Clark \& Kirisci, 1996; DeWit, McDonald \& Offord, 1999).

Social phobia has been assessed using different types of approaches: interviews, self-reports, selfmonitoring, behavioral observations forms and psychophysiological recordings (Beidel \& Turner, 2005; Rey-Anacona, Mejía \& Montoya, 2008). One of the instruments that have shown better psychometric properties and greater sensibility to therapeutic changes is the Social Phobia and Anxiety Inventory (SPAI) (Turner, Beidel, Dancu \& Stanley, 1989). Designed initially to be used with adult populations it has proven to be reliable and valid for both English and Spanish speaking adolescents (Clark, Turner, Beidel, Donovan, Kirisci \& Jacob, 1994; García-López, Olivares, Hidalgo, Beidel \& Turner, 2000; Olivares, García-López, Hidalgo, Turner \& Beidel, 1999). SPAI consists of 45 items of which 32 assess social anxiety responses and 13 agoraphobics, and includes three scores: the score for the Social Phobia subscale, the score for the Agoraphobia subscale and the Difference score, which is obtained from the substraction of the two previous scores. Today there is still controversy about which is the best SPAI measure to evaluate social phobia. Turner, Stanley, Beidel, and Bond (1989) stated that the Difference score was the most appropriate but a subsequent study found that the Social Phobia subscale could be the most adequate (Herbert, Bellack \& Hope, 1991). Herbert, Bellack, Hope, and Mueser (1992) suggested that the choice about which score to use should be determined by the purpose of the study. Therefore, the Difference score could be used when the goal is to carry on a differential diagnosis with agoraphobia and the Social Phobia subscale could be used if the goal is to evaluate the effectiveness of psychological treatments for social phobia. On the other hand, Cox, Ross, Swinson, and Direnfeld (1998), and Ries, McNeil, Boone, Turk, Carter, and Heimberg (1998) stated that the use of the Social Phobia score could be the more parsimonious measure to assess social anxiety.

Besides this controversy, several studies have analyzed the reliability and validity of the instrument. A high test-retest reliability $(0.86)$ and internal consistency for the subscales of Social Phobia (0.96) and Agoraphobia (0.85) has been reported (Turner et al., 1989). Subsequent studies in English speaking populations have found similar indicators of internal consistency for the subscales: 0.96 and 0.86 , in community samples, and 0.94 and 0.83 , in a university sample (Osman, Barrios, Haupt, King, Osman \& Slavens, 1996). Furthermore, Bögels and Reith (1999) have also found SPAI to be valid and reliable in a German speaking sample.

With respect to construct validity, some studies have shown that SPAI has been able to discriminate between subjects with social phobia and those with other anxiety disorders (Peters, 2000; Turner, Stanley, Beidel \& Bond, 1989).

The first objective of this paper was the adaptation of the SPAI version used by Olivares et al. (1999) to the sociolinguistic reality of Chile so that it could be subsequently applied to a sample of an adolescent population. The second objective was to analyze the structural validity of the scale, including its factorial structure as well as the reliability of the resultant constructs in the measurement of the social anxiety construct. To complement this study of structural validity, a third and last objective, was to conduct a descriptive analysis of social anxiety among Chilean adolescents as a function of sex and age. 


\section{Method}

\section{Participants}

One thousand non clinical adolescents of Santiago de Chile (Chile) participated in this study. The mean age was 15.62 ( $\mathrm{SD}=1.24$; range: $13-18$ years). $22.18 \%$ of the subjects were between $13-14$ years (10.51\% males and $11.67 \%$ females), $49.57 \%$ were between $15-16$ years $(20.93 \%$ males and $28.64 \%$ females) and the remainder $28.25 \%$ was in the $17-18$ interval $(10.41 \%$ males and $17.84 \%$ females). Subjects were from a mid-low socioeconomic level and attended a high school randomly selected among the different educational centers that exist in Santiago, Chile.

\section{Procedure}

The procedure followed the following stages:

1. Contextualization of the instrument. In this stage the appropriateness of the items to the Chilean sociocultural context was reviewed. In the first review several Spanish words not frequently used in Chile were changed. For example "bar" was used instead of "pub", "tomo" instead of "bebo" (item 20) and "micro" instead of "autobús", "llenos" replaced "abarrotados" (item 30) and "auto" was used instead of "coche".

2. An interview with the directors of the participant centers was conducted to explain the objectives of the study; describe the assessment instrument and ask for permission and promote their cooperation. We follow this procedure: the copies were distributed, the sections related to demographic data were first filled in and the instructions were read aloud emphasizing the importance of not letting questions unanswered. Finally, doubts that the participants might have were taken care of trying no to influence their responses. The researchers were present during the administration of the instrument to provide information if needed, to verify that the items were responded correctly and independently, and that demographic data had been appropriately noted.
3. Pilot Study. This phase meets the objective of evaluating the appropriateness of the modifications mentioned above and verifies the need for further adjustments. In this way the instrument was administered to 30 participants between 13 and 18 years old, both males and females with the purpose of determining some issues related to its application such as duration, comprehension of the items, etc. It was indicated to the participants that any doubt should be resolved with the evaluator, fulfilling in this way the objective of detecting possible difficulties that the questionnaire could present to the target population. No difficulties were encountered in the comprehension of the instructions. The time to complete the questionnaire ranged from 15-20 minutes. It was not necessary to make modifications either to the relevance of the instrument or to its form of administration.

4. Final Application. In each application two previously trained administrators participated providing general information about the way to answer the test and the confidentiality of the data obtained.

\section{Psychometric Study}

Before conducting any statistical analysis a score per item was obtained following the procedure used by Turner et al. (1989). Then the psychometric study was done through the following phases:

i. Study of the structural validity of the test with the purpose of determining if in our sample the bifactorial structure predicted by the test was reproduced. To achieve this we applied a exploratory common factor analysis, using the factorization of principal axes implemented in the SPSS 15.0, using the Cattell scree-plot and the percentage of variance explained in order to obtain the best factorial solution that reproduced the original correlation matrix. The non-rotated factorial solution was submitted to both rotation procedures (orthogonal and oblique) with the purpose of finding a better 
explanation of the results obtained, however only the oblique solution is reported.

ii. For each of the resulting significant factors an item analysis was conducted (means and homogeneity indices) and the alpha reliability coefficients were calculated to study the precision of the scores obtained.

iii. For each one of the factors statistical analyses as a function of the controlled variables in the study (sex and age) were conducted in order to look for evidence of the empirical validity of these attributes.

\section{Results}

\section{Structural Validity}

Before applying the factor analysis, the factorization of the correlation matrix between the 45 items was tested using the sample appropriateness of Kaiser-Mayer-Olkin (KMO) and the Barlett sphericity test. The magnitude of the $\mathrm{KMO}$ measurement was of 0.959 and the sphericity test was highly significant (chi-square $=17007.081, \mathrm{df}=990, \mathrm{p}=$ 0.000 ), therefore the correlation matrix of the 45 items of the SPAI, in this sample, can be factorially analyzed. Table 1 presents the first ten eigenvalues as a function of the variables (items) under study. Figure 1 shows the scree-plot of Catell.

TABLE 1

Eigenvalues of the ten first factors as a function of the SPAI test items

\begin{tabular}{cccc}
\hline \multirow{2}{*}{ Factor } & \multicolumn{3}{c}{ Non rotated eigenvalues } \\
\cline { 2 - 4 } & Total & \% of variance & \% accumulated \\
\hline 1 & 16.619 & 36.931 & 36.931 \\
2 & 2.904 & 6.453 & 43.384 \\
3 & 1.450 & 3.222 & 46.606 \\
4 & 1.353 & 3.007 & 49.613 \\
5 & 1.312 & 2.915 & 53.528 \\
6 & 1.152 & 2.561 & 55.089 \\
7 & 1.032 & 2.294 & 57.383 \\
8 & 0.965 & 2.144 & 59.528 \\
9 & 0.928 & 2.061 & 61.589 \\
10 & 0.902 & 2.005 & 63594 \\
\hline
\end{tabular}

Source: own work.

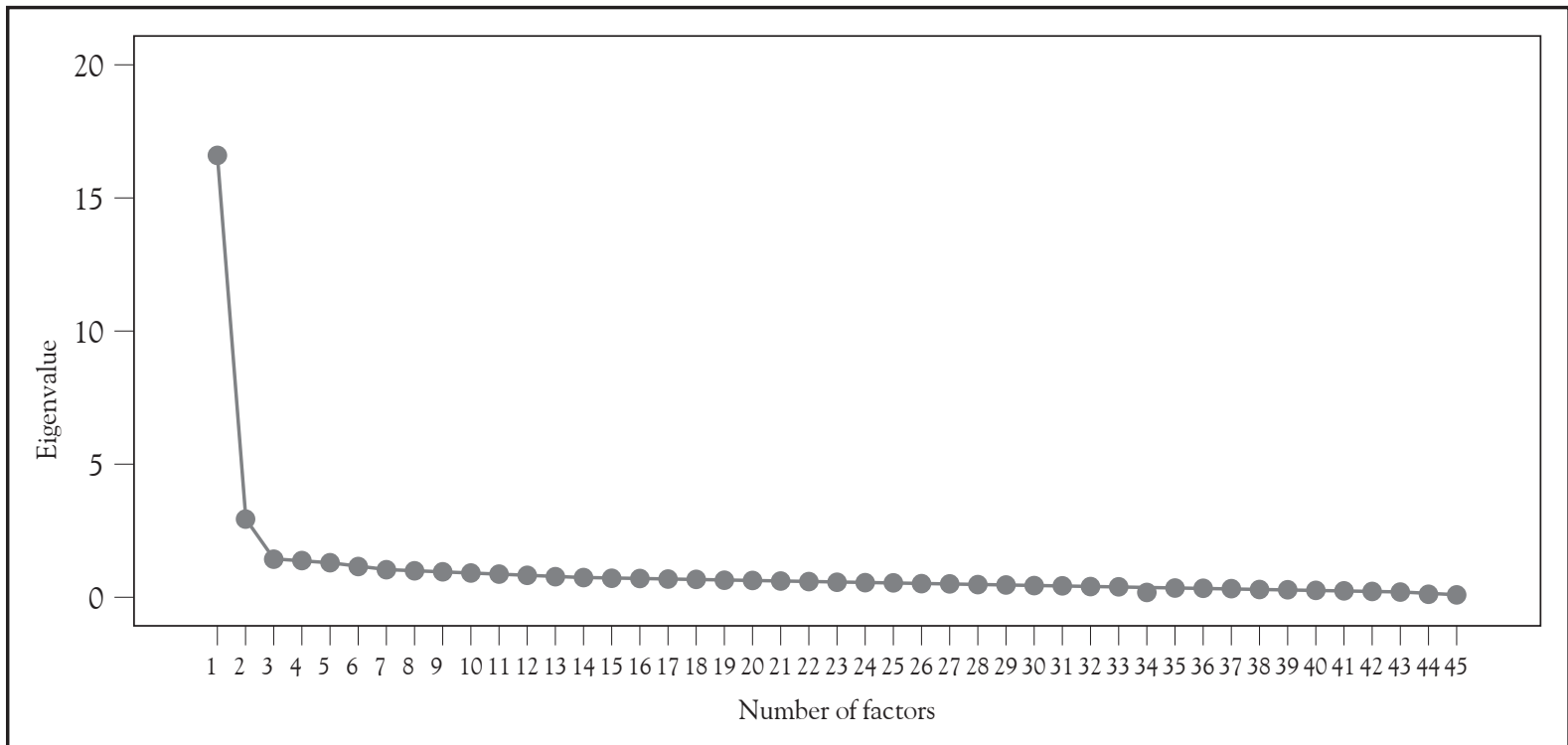

Figure 1

Cattel's Scree-plot of the SPAI test.

Source: own work. 
The Catell scree-plot (Figure 1) with the eigenvalues obtained in the factor solution (Table 1) suggested that a bidimensional solution that explained $43.38 \%$ of the total variance was a good representation of the dimensionality underlying to the SPAI. This percentage is considered enough to obtain an interpretative solution when the common factor analysis is used (Pett, Lackey \& Sullivan, 2003; Tabachnick \& Fidell, 1996). Then we rotated the two factors to find out a simpler explanatory structure. We opted for an oblique rotation (promax) rather than orthogonal since in these type of tests is likely that the factors be correlated; only in the case that the correlation between the two factors is very low the orthogonal solution is preferred over the oblique (Gorsuch, 1983). In our analysis the correlation obtained between the two oblique factors was 0.641 ; therefore this was the adopted solution according to the criteria of simple structure.

Table 2 shows the factor patterns matrix and the structure matrix; both are necessary to make an appropriate interpretation of the oblique factors. Thus, items 1 through 32 loaded basically in the Social Phobia subscale, while items 33 through 45 loaded in the agoraphobia subscale. Successive factor analysis with promax oblique rotation on this sample as a function of sex, age and random sub-samples gave the same factor structure that appears in Table 2. Since the number of tables is too high, these results are not included but can be requested from the authors.

TABLE 2

Factors pattern matrix and structure matrix of the STAI test

\begin{tabular}{ccccc}
\hline \multirow{2}{*}{ Items } & \multicolumn{2}{c}{$\begin{array}{c}\text { Factors pattern } \\
\text { matrix }\end{array}$} & \multicolumn{2}{c}{$\begin{array}{c}\text { Factor structure } \\
\text { matrix }\end{array}$} \\
\cline { 2 - 5 } & Factor I & Factor II & Factor I & Factor II \\
\hline 1 & .640 & -.105 & .573 & .306 \\
2 & .735 & -.084 & .681 & .388 \\
3 & .717 & -.132 & .633 & .328 \\
4 & .609 & -.018 & .597 & .372
\end{tabular}

\begin{tabular}{|c|c|c|c|c|}
\hline \multirow{2}{*}{ Items } & \multicolumn{2}{|c|}{$\begin{array}{l}\text { Factors pattern } \\
\text { matrix }\end{array}$} & \multicolumn{2}{|c|}{$\begin{array}{c}\text { Factor structure } \\
\text { matrix }\end{array}$} \\
\hline & Factor I & Factor II & Factor I & Factor II \\
\hline 5 & .671 & -.086 & .616 & .345 \\
\hline 6 & .642 & -.130 & .559 & .282 \\
\hline 7 & .690 & -.161 & .587 & .282 \\
\hline 8 & .526 & -.034 & .504 & .303 \\
\hline 9 & .848 & -.050 & .816 & .493 \\
\hline 10 & .880 & -.087 & .824 & .477 \\
\hline 11 & .668 & .094 & .728 & .522 \\
\hline 12 & .814 & -.027 & .796 & .494 \\
\hline 13 & .652 & .053 & .686 & .471 \\
\hline 14 & .785 & -.121 & .708 & .382 \\
\hline 15 & .372 & .062 & .411 & .300 \\
\hline 16 & .681 & .056 & .717 & .493 \\
\hline 17 & .425 & .151 & .521 & .423 \\
\hline 18 & .733 & -.021 & .720 & .449 \\
\hline 19 & .740 & .052 & .773 & .526 \\
\hline 20 & .401 & .260 & .568 & .517 \\
\hline 21 & .360 & .224 & .504 & .455 \\
\hline 22 & .733 & .046 & .763 & .516 \\
\hline 23 & .605 & .066 & .647 & .453 \\
\hline 24 & .626 & .028 & .644 & .430 \\
\hline 25 & .496 & .127 & .577 & .445 \\
\hline 26 & .565 & .165 & .671 & .527 \\
\hline 27 & .730 & .016 & .740 & .484 \\
\hline 28 & .545 & .134 & .630 & .483 \\
\hline 29 & .555 & .030 & .574 & .385 \\
\hline 30 & .573 & .182 & .690 & .549 \\
\hline 31 & .509 & .232 & .658 & .558 \\
\hline 32 & .550 & .242 & .705 & .594 \\
\hline 33 & -.066 & .532 & .275 & .489 \\
\hline 34 & .281 & .371 & .519 & .551 \\
\hline 35 & -.033 & .637 & .376 & .616 \\
\hline
\end{tabular}




\begin{tabular}{ccccc}
\hline \multirow{2}{*}{ Items } & \multicolumn{2}{c}{$\begin{array}{c}\text { Factors pattern } \\
\text { matrix }\end{array}$} & \multicolumn{2}{c}{$\begin{array}{c}\text { Factor structure } \\
\text { matrix }\end{array}$} \\
\cline { 2 - 5 } & Factor I & Factor II & Factor I & Factor II \\
\hline 36 &. .054 & .592 & .325 & .557 \\
37 & .116 & .563 & .477 & .637 \\
38 & .006 & .648 & .421 & .652 \\
39 & -.064 & .627 & .337 & .585 \\
40 & -.071 & .589 & .306 & .544 \\
41 & -.070 & .619 & .327 & .574 \\
42 & -.017 & .616 & .378 & .605 \\
43 & .002 & .334 & .216 & .335 \\
44 & -.087 & .604 & .300 & .548 \\
45 & .043 & .542 & .391 & .570 \\
\hline
\end{tabular}

Source: own work.

\section{Analysis of the subscales}

Once the bifactorial structure was determined we proceeded to study the internal characteristics (analysis of items and reliability) of each subscale.

\section{Social Phobia Scale}

Table 3 shows the analysis of the 32 items that form the Social Phobia subscale. The most homogeneous item was item $10(\mathrm{IH}=0.764)$, while the one with the lowest homogeneity index was $15(\mathrm{IH}$ $=0.481)$. All items were within the $(0.30-0.70)$ interval recommended by Crocker and Algina (1986) as good indicators of the construct. On the other hand the mean of the item tells of the place that each one of them occupy in the continuum as good indicators of the construct of Social Phobia. In this way item 5 (Mean $=4.099)$, item $26($ Mean $=3.981)$ and item $14($ Mean $=3.926)$ represent the actions valued by the subjects as most indicative of social phobia, while item 31 (Mean = $1.827)$ and item $8($ Mean $=1.857)$ are the actions valued by the subjects as the lowest indicators of social phobia. Any item obtained a mean greater than 4.099 (item 5).
TABLE 3

Item analysis of the Social Phobia subscale

\begin{tabular}{|c|c|c|c|c|}
\hline Item & Mean & $\begin{array}{l}\text { Standard } \\
\text { deviation }\end{array}$ & $\begin{array}{l}\text { Homogeneity } \\
\text { Index }\end{array}$ & $\begin{array}{l}\text { Reliability } \\
\text { Index }\end{array}$ \\
\hline 1 & 2.429 & 1.320 & 0.544 & 0.718 \\
\hline 2 & 3.264 & 1.624 & 0.672 & 1.091 \\
\hline 3 & 3.527 & 1.798 & 0.614 & 1.103 \\
\hline 4 & 2.841 & 1.640 & 0.593 & 0.973 \\
\hline 5 & 4.099 & 1.901 & 0.612 & 1.164 \\
\hline 6 & 2.679 & 1.624 & 0.544 & 0.883 \\
\hline 7 & 2.576 & 1.601 & 0.560 & 0.897 \\
\hline 8 & 1.857 & 1.340 & 0493 & 0.660 \\
\hline 9 & 2.526 & 1.364 & 0.740 & 1.010 \\
\hline 10 & 2.811 & 1.490 & 0.764 & 1.138 \\
\hline 11 & 2.193 & 1.376 & 0.652 & 0.897 \\
\hline 12 & 2.903 & 1.594 & 0.747 & 1.190 \\
\hline 13 & 2.743 & 1.529 & 0.686 & 1.049 \\
\hline 14 & 3.926 & 1.749 & 0.690 & 1.207 \\
\hline 15 & 2.623 & 1.544 & 0.481 & 0.742 \\
\hline 16 & 2.389 & 1.440 & 0.716 & 1.030 \\
\hline 17 & 2.079 & 1.321 & 0.558 & 0.736 \\
\hline 18 & 2.749 & 1.431 & 0.729 & 1.043 \\
\hline 19 & 2.578 & 1.414 & 0.760 & 1.075 \\
\hline 20 & 2.215 & 1.562 & 0.572 & 0.893 \\
\hline 21 & 2.134 & 1.542 & 0.571 & 0.881 \\
\hline 22 & 2.680 & 1.560 & 0.759 & 1.184 \\
\hline 23 & 3.444 & 1.827 & 0.659 & 1.204 \\
\hline 24 & 2.508 & 1.501 & 0.654 & 0.981 \\
\hline 25 & 2.165 & 1.304 & 0.577 & 0.752 \\
\hline 26 & 3.981 & 2.163 & 0.662 & 1.431 \\
\hline 27 & 3.269 & 1.905 & 0.733 & 1.396 \\
\hline 28 & 2.901 & 1.929 & 0.656 & 1.265 \\
\hline 29 & 3.255 & 2.021 & 0.602 & 1.216 \\
\hline
\end{tabular}




\begin{tabular}{ccccc}
\hline Item & Mean & $\begin{array}{c}\text { Standard } \\
\text { deviation }\end{array}$ & $\begin{array}{c}\text { Homogeneity } \\
\text { Index }\end{array}$ & $\begin{array}{c}\text { Reliability } \\
\text { Index }\end{array}$ \\
\hline 30 & 2.641 & 1.554 & 0.668 & 1.038 \\
31 & 1.827 & 1.116 & 0.617 & 0.688 \\
32 & 3.037 & 1.796 & 0.669 & 1.201 \\
\hline
\end{tabular}

Source: own work.

The reliability analysis revealed that scores obtained in the Social Phobia scale was highly reliable (alpha coefficient $=0.953$ ), the confidence interval (95\%) of the alpha coefficient varying between 0.948 and 0.957 , according to the Hakstian and Whalen (1976) procedure.

\section{Agoraphobia Subscale}

Table 4 presents the analysis of the items of the Agoraphobia subscale. The most homogeneous item was $10(\mathrm{IH}=0.654)$ while the least homogeneous was $11(\mathrm{IH}=0.463)$. Once again all the items obtained homogeneity indices within the $0.30-0.70$ interval (Crocker \& Algina, 1986), confirming the results obtained in the factor analysis. On the other hand item $2($ Mean $=3.255)$ and item 11 (Mean $=3.167$ ) obtained the highest means. These means showed that this sample consider that these actions are high indicators of Agoraphobia, while item $12($ Mean $=1.398)$ and item $4($ Mean $=1.481)$ that obtained the lowest values are located in the opposite extreme.

TABLE 4

Item analysis of the Agoraphobia subscale

\begin{tabular}{ccccc}
\hline Item & Mean & $\begin{array}{c}\text { Standard } \\
\text { deviation }\end{array}$ & $\begin{array}{c}\text { Homogeneity } \\
\text { Index }\end{array}$ & $\begin{array}{c}\text { Reliability } \\
\text { Index }\end{array}$ \\
\hline 1 & 1.539 & 1.271 & 0.506 & 0.643 \\
2 & 3.255 & 1.852 & 0.637 & 1.180 \\
3 & 2.038 & 1.587 & 0.640 & 1.015 \\
4 & 1.481 & 0.992 & 0.580 & 0.575 \\
5 & 1.671 & 1.209 & 0.631 & 0.763 \\
6 & 1.501 & 1.086 & 0.617 & 0.670 \\
7 & 2.239 & 1.710 & 0.637 & 1.090
\end{tabular}

\begin{tabular}{ccccc}
\hline Item & Mean & $\begin{array}{c}\text { Standard } \\
\text { deviation }\end{array}$ & $\begin{array}{c}\text { Homogeneity } \\
\text { Index }\end{array}$ & $\begin{array}{c}\text { Reliability } \\
\text { Index }\end{array}$ \\
\hline 8 & 2.743 & 1.933 & 0.627 & 1.212 \\
9 & 1.835 & 1.486 & 0.604 & 0.897 \\
10 & 2.422 & 1.716 & 0.654 & 1.123 \\
11 & 3.167 & 1.977 & 0.463 & 0.916 \\
12 & 1.398 & 0.979 & 0.553 & 0.542 \\
13 & 2.009 & 1.492 & 0.615 & 0.918 \\
\hline
\end{tabular}

Source: own work.

The reliability analysis showed that the scores obtained in the Agoraphobia subscale was slightly less reliable than Social Phobia subscale. Thus the alpha coefficient obtained in this scale was 0.839 , with the confidence interval (95\%) varying between 0.824 and 0.852 (Hakstian \& Whalen, 1976).

\section{Inferential analysis of social anxiety in adolescence}

Tables 5 and 6 present the descriptive statistics (mean, standard deviation, minimum and maximum) for each one of the two subscales, social phobia and agoraphobia, as a function of sex and age. Anticipating likely differences between sex and age and a significant interaction between both effects in the SPAI, we did an ANOVA of sex by age in the Social Phobia and Agoraphobia subscales. Results showed that in the Social Phobia subscale significant differences were found among the sample components as a function of sex $(\mathrm{F}=$ 5.676, $\mathrm{df}=1,689, \mathrm{p}=.017)$ and age $(\mathrm{F}=2.274$, $\mathrm{df}=5,689, \mathrm{p}=0.046)$, but the interaction was not significant $(\mathrm{F}=2.129, \mathrm{df}=5,689, \mathrm{p}=.060)$. However the magnitude of the effects of the differences found as function of sex $\left(\eta^{2}=.008\right)$ and age $\left(\eta^{2}=.016\right)$ were very small, confirming that the statistical significance might be due to the high power of the study, given that a very large sample was employed (Cohen, 1990). This fact is also supported by the Bonferroni post hoc test that found no significant difference when comparing the means of the different age groups. 
TABLE 5

Descriptive statistics of the Social Phobia subscale in the Chilean adolescent simple as a function of sex and age

\begin{tabular}{ccccccccc}
\hline & \multicolumn{7}{c}{ Age } \\
\cline { 3 - 8 } & & 13 & 14 & 15 & 16 & 17 & 18 & Total \\
\hline \multirow{2}{*}{ Female } & Mean & 133.19 & 90.64 & 93.67 & 98.82 & 92.21 & 77.24 & 93.35 \\
& SD & 34.43 & 38.71 & 33.15 & 37.78 & 34.02 & 32.38 & 36.29 \\
\multirow{2}{*}{ Male } & Mean & 91.50 & 81.03 & 91.48 & 86.59 & 80.70 & 92.21 & 85.68 \\
& SD & 38.25 & 23.88 & 33.42 & 28.29 & 28.89 & 38.89 & 30.16 \\
\multirow{2}{*}{ Total } & Mean & 110.03 & 85.71 & 92.28 & 91.85 & 84.40 & 85.84 & 88.81 \\
& SD & 40.73 & 32.42 & 33.17 & 33.01 & 31.06 & 36.66 & 32.92 \\
\hline
\end{tabular}

Source: own work.

On the other hand, in the Agoraphobia subscale we found again significant differences as a function of sex $(\mathrm{F}=29.683, \mathrm{df}=1,979, \mathrm{p}=$ $0.000)$, while in the age variable $(\mathrm{F}=1.7 \mathrm{df}=$ $5,979, \mathrm{p}=0.132$ ) no significant differences were found between the ages, but the interaction between both variables was significant $(\mathrm{F}=3.035$, $\mathrm{df}$ $=5,979, \mathrm{p}=0.01)$. However, none of the fixed magnitude effects sex $\left(\eta^{2}=.029\right)$, age $\left(\eta^{2}=.009\right)$ and their interaction $\left(\eta^{2}=.015\right)$ was important enough so as to consider that the statistical significance has been obtained because due to a factor different from the high number of the sample employed in this study.

\section{Conclusions}

The treatment of social phobia requires that valid and reliable instruments be available to confirm its presence and to evaluate treatment efficacy in the cases it is applied. In spite of the high levels of incidence found worldwide there is still a need for evaluation instruments built or adapted for its use with Chilean adolescents affected by this disturbance.

Transcultural validation allows that the results found through different studies can be included in a discussion in an international context. Therefore when instruments have been found to have good

TABLE 6

Descriptive statistics of the Agoraphobia subscale in the Chilean adolescent simple as a function of sex and age

\begin{tabular}{|c|c|c|c|c|c|c|c|c|}
\hline & & \multicolumn{7}{|c|}{ Age } \\
\hline & & 13 & 14 & 15 & 16 & 17 & 18 & Total \\
\hline \multirow{2}{*}{ Female } & Mean & 42.40 & 31.27 & 29.47 & 31.29 & 31.89 & 24.17 & 30.68 \\
\hline & SD & 6.77 & 12.73 & 13.33 & 13.03 & 12.32 & 8.31 & 12.86 \\
\hline \multirow{2}{*}{ Male } & Mean & 23.29 & 25.09 & 26.76 & 23.96 & 24.50 & 24.44 & 25.03 \\
\hline & SD & 10.61 & 9.42 & 11.59 & 9.35 & 9.48 & 7.54 & 9.95 \\
\hline \multirow{2}{*}{ Total } & Mean & 31.25 & 28.05 & 27.89 & 26.99 & 27.08 & 24.32 & 27.38 \\
\hline & SD & 13.23 & 11.51 & 12.41 & 11.56 & 11.11 & 7.81 & 11.58 \\
\hline
\end{tabular}

Source: own work. 
psychometric properties, the first task is to translate, adapt and validate them before creating new ones (Olivares, Piqueras \& Sánchez-García, 2004; Vera-Villarroel, Olivares, Kuhne, Rosa-Alcázar, Santibáñez \& López-Pina, 2007).

Our first objective was to adapt the SPAI to the cultural and social reality of the Chilean adolescent population, analyzing the linguistic structure of the items and modifying some words and substitute for others more commonly used by the Chilean population. After these modifications the instrument was adapted to be used with the population. The result was an instrument that did not present any difficult to be applied and understood, with clear, comprehensible instructions and reactives for the target population and with a relatively short time for application (15 to 20 minutes).

With respect to our second objective, the data suggested that two clearly differentiated dimensions existed in the SPAI: a Social Phobia subscale and an Agoraphobia subscale. These data can be supported with the reliability indicators of the different subscales. We can see that the internal consistency (alpha coefficient) of the social phobia and the agoraphobia subscales is very high $(0.95$ and 0.84, respectively). Results showed a high internal consistency of the items supporting therefore the existence of two factors as in the Olivares et al. (1999) study with a Spaniard adolescent population.

These data were consistent with what has been reported by other authors. Turner et al (1989) in its original version found a high test-retest reliability (0.86) and internal consistency for the Social Phobia subscale (0.96) and Agoraphobia (0.85). Later, Osman et al. (1996) found similar levels of internal consistency for the subscales: $0.96 \mathrm{y}$ 0.86 in community samples and 0.94 and 0.83 in a university sample. More recently and in a Spanish version the results obtained by Olivares et al. (1999) also showed appropriate coefficient of internal consistency ( 0.95 and 0.83 for the Social Phobia and Agoraphobia subscales respectively). Therefore this is an instrument with high reliability.

With respect to the results of the homogeneneity indexes we can conclude that only few of the community sample subjects presented very high scores in Social Phobia given that no item obtained a higher score than 4.099 (item 5). This makes us realize the importance of increasing the sample in order to be able to generalize the results obtained.

Regarding our third objective, the descriptive analysis of social anxiety in Chilean adolescents as a function of sex and age, the data obtained from both subscales indicate that differences existed with respect to sex; the girls' scores were higher than those of the boys'. These results are consistent with those obtained by Inderbitzen, Walters and Bukowski (1997), La Greca, and López (1998) and Sandín, Chorot, Valiente, Santed, and SánchezArribas (1999). It is likely therefore that the Chilean girls are more vulnerable to experience social anxiety than the boys in this country. However we must mention that there is no consensus with respect to the existence of a higher prevalence of social anxiety either in men or women. Although the majority of studies indicate a higher prevalence for women, a review of the clinical studies showed that the percentage of males is equal or superior to that the females (Beidel \& Turner, 2005; Rosa, Olivares \& Olivares-Olivares, 2007). Therefore, it is still no clear which variables were the ones that explain better these findings. Furmark, Tillfors, Everz, Murteinsdottir, Gefvert, and Fredrikson (1999) stated that maybe the differences were due to the way in which the information was gathered, the type of instrument, the population, the way roles are structured in different cultures, and others. With respect to the influence of age in Social Phobia, in our study statistically significant differences were found in the Social Phobia subscale but not in the Agoraphobia subscale. The post-hoc tests, however, did not find significant differences between the means in this last subscale. On the other hand the effect size of the differences found were very small, which makes us think that the statistical significance found in some of the variables might be due to the power of the study since a very large sample was employed. However, we need more studies to clarify more precisely this issue in the Chilean population, while at the same time study the differences paying attention to the 
modality of the population studied (clinical versus community), to the Phobia Social subtype and to the comorbidity that some persons might present.

On the other hand the analysis of the convergent and discriminant validity as well as its diagnostic capacity (predictive validity) is also pending of study. Moreover, given that social phobia precedes other anxiety and mood disorders (Beidel \& Turner, 2005; Rappaport, Paniccia \& Judd, 1995), it is necessary to continue adapting instruments to our population that would permit an early detection of the disturbance so that our interventions can be more efficient (Castillo, Pérez-Salas, Bravo, Gancino, Catalán \& Acosta, 2008).

Finally we can conclude that the results of this study showed high indicators of homogeneity of the Social Anxiety Inventory for each one of the subscales and thus confirms the structure of two factors originally formulated for the instrument, providing empirical support to the utilization of this test in an adolescent middle to low socioeconomic status sample of adolescents in Santiago, Chile.

\section{References}

American Psychiatric Association. (2000). Diagnostic and Statistical Manual of Mental Disorders (4th $\mathrm{ed}$., revised text). Washington, DC: Author.

Beidel, D. C. \& Turner, S. M. (2005). Childhood anxiety disorders. A guide to research and treatment. Nueva York: Routledge.

Bögels, S. M. \& Reith, W. (1999). Validity of two questionnaires to assess social fears: The Dutch Social Phobia and Anxiety Inventory and the Blushing, Trembling and Sweating Questionnaire. Journal of Psychopathology and Behavioral Assessment, 21, 51-66.

Castillo, R. D., Pérez-Salas, C. C., Bravo, C., Gancino, M. G., Catalán, J. \& Acosta, H. C. (2008). Diseño y Validación de una Escala de Competencia Comunicativa y Social para Niños [Design and Validation of a Scale of Communicative and Social Skill for Children]. Terapia Psicología, 26(2), 173-180.
Clark, D. B. \& Kirisci, L. (1996). Postraumatic stress disorder, depression, alcohol use and quality of life in adolescents. Anxiety, 2, 226-233.

Clark, D. B., Turner, S. M., Beidel, D. C., Donovan, J. E., Kirisci, L. \& Jacob, R. G. (1994). Reliability and validity of the Social Phobia and Anxiety Inventory for adolescents. Psychological Assessment, 6, 135-140.

Cohen, J. (1990). Things I have learned (so far). American Psychologist, 45 (12), 1304-1312.

Crocker, L. \& Algina, J. (1986). Introduction to classical and modern test theory. New York: Holt, Rinehart and Winston.

Cox, B. J., Ross, L., Swinson, R. P. \& Direnfeld, D. M. (1998). A comparison of social phobia outcome measures in cognitive-behavioral group therapy. Behavior Modification, 22, 285-297.

DeWitt, D. J., McDonald, K. \& Offord, D. R. (1999). Childhood stress and symptoms on drug dependence in adolescence and early adulthood: Social phobia as a mediator. American Journal of Orthopsychiatry, 69, 61-72.

Essau, C. A., Conradt, J. \& Petermann, F. (1999). Frecuency and comorbidity of social phobia and social fears in adolescents. Behaviour Research and Therapy, 37, 831-843.

Furmark, T., Tillfors, M., Everz, P. O., Marteinsdottir, I., Gefvert, O. \& Fredrikson, M. (1999). Social phobia in the general population, prevalence and sociodemographic profile. Social Psychiatry and Psychiatric Epidemiology, 34, 416-424.

García-López, L. J., Olivares, J., Hidalgo, M. D., Beidel, D. C. \& Turner, S. M. (2000). Psychometric properties of the Social Phobia and Anxiety Inventory, the Social Anxiety Scale for Adolescents, the Fear of Negative Evaluation scale and the Social Avoidance Distress scale in an adolescent Spanish speaking population. Journal of Psychopathology and Behavioral Assessment, 23, 51-59.

Gorsuch, R. L. (1983). Factor analysis (2 ed.). Hillsdale, NJ: LEA.

Hakstian, A. R. \& Whalen, T. E. (1976). A K-sample significance test for independent alpha coefficients. Psychometrika, 41, 219-231. 
Hayward, C., Killen, J. D., Kraemer, H. C. \& Taylor, C. B. (1998). Linking self-reported childhood behavioral inhibition to adolescent social phobia. Journal American Academic Child Adolescence Psychiatry, 37, 1308-1316.

Herbert, J. D., Bellack, A. S. \& Hope, D. A. (1991). Concurrent validity of the Social Phobia and Anxiety Inventory. Journal of Psychopathology and Behavioral Assessment, 13, 357-368.

Herbert, J. D., Bellack, A. S., Hope, D. A. \& Mueser, K. T. (1992). Scoring the Social Phobia and Anxiety Inventory: Reply to Beidel and Turner. Journal of Psychopathology and Behavioral Assessment, 14, 381-383.

Inderbitzen, H. M., Walters, K. S. \& Bukowski, A. L. (1997). The role of social anxiety in adolescent peer relations: Differences among sociometric status groups and rejected subgroups. Journal of Clinical Child Psychology, 26, 338-348.

Ingram, R. E., Ramel, W., Chavira, D. \& Scree, C. (2001). Social anxiety and depression En W. R. Crozier \& L. E. Alden (Eds.), International Handbook of Social Anxiety: Concepts, Research and Interventions Relating to the Self and Shyness (pp. 357-380). New York: John Wiley \& Sons Ltd.

La Greca, A. M. \& López, N. (1998). Social anxiety among adolescents: Linkages with peer relations and friendships. Journal of Abnormal Child Psycho$\log y, 26,83-94$.

Olivares, J. \& García-López, L. J. (2001). Un nuevo tratamiento multicomponentes para adolescentes con fobia social generalizada: resultados de un estudio piloto. [A new multicomponent treatment for adolescents with social phobia: Results of a pilot study]. Psicología Conductual, 9, 247-254.

Olivares, J., García-López, L. J., Hidalgo, M. D., Turner, S. M. \& Beidel, D. C. (1999). The Social Phobia and Anxiety Inventory: Reliability and validity in a Spanish adolescent population. The Journal of Psychopathology and Behavioral Assessment, 21, 67-78.

Olivares, J., Piqueras, J. Sánchez-García, R. (2004). Escala para la detección de la ansiedad social (EDAS). Estructura factorial y fiabilidad en una muestra de adolescentes entre 14 y 18 años. Psicología Conductual, 12, 251-268
Osman, A., Barrios, F. X., Aukes, D. \& Osman, J. R. (1995). Psychometric evaluation of the Social Phobia and Anxiety Inventory in college students. Journal of Clinical Psychology, 51, 235-243.

Osman, A., Barrios, F. X., Haupt, D., King, K., Osman, J. R. \& Slavens, S. (1996). The Social Phobia and Anxiety Inventory: Further validation in two nonclinical samples. Journal of Psychopathology and Behavioral Assessment, 18, 35-47.

Peters, L. (2000). Discriminant validity of the Social Phobia and Anxiety Inventory (SPAI), the Social Phobia Scale (SPS) and the Social Interaction Anxiety Scale (SIAS). Behaviour Research and Therapy, 38, 943-950.

Pett, M. A., Lackey, N. R. \& Sullivan, J. R. (2003). Making sense of factor analysis. CA: Sage.

Rapapport, M. H., Paniccia, G. \& Judd, L. L. (1995). A review of social phobia. Psychopharmacological Bulletin, 31, 125-129.

Ries, B. J., McNeil, D. W., Boone, M. L., Turk, C. L., Carter, L. E. \& Heimberg, R. G. (1998). Assessment of contemporany social phobia verbal instruments. Behaviour Research and Therapy, 36, 983-994.

Rey-Anacona, C. A., Mejía, D. C. \& Montoya, C. E. (2008). Evaluación de la confiabilidad y la validez de un cuestionario breve de autoinforme para el diagnóstico de la fobia social [Reliability and Validity of a Brief Self-Report Questionnaire for the Diagnosis of Social Phobia]. Universitas psychologica, 7(2), 477-491.

Rosa, A. I., Olivares, J. \& Olivares-Olivares, P. J. (2007). Papel de la planificación de la interacción en el tratamiento de adolescentes con fobia social generalizada [The role of planned interaction in the treatment of generalizad social phobia]. Terapia Psicología, 25 (2), 205-212.

Sandín, B., Chorot, P., Valiente, R. M., Santed, M. A. \& Sánchez-Arribas, C. (1999). Estructura factorial de la escala de ansiedad social para niños-revisada (SASC-R) [Factorial structure of the social anxiety scale for children- revised]. Revista de Psicopatología y Psicología Clínica, 4, 105-113.

Tabachnick, B. G. \& Fidell, L. S. (1996). Using multivariate statistics. Boston: Pearson.

Turner, S. M., Beidel, D. C., Dancu, C. V. \& Stanley, M. A. (1989). An empirically derived inventory 
to measure social fears and anxiety: The Social Phobia and Anxiety Inventory. Psychological Assessment, 1, 35-40.

Turner, S. M., Stanley, M. A., Beidel, D. C. \& Bond, L. (1989). The Social Phobia and Anxiety Inventory: Construct validity. Journal of Psychopathology and Behavioral Assessment, 11, 221-234.

Vera-Villarroel, P., Olivares, J. Kuhne, W., Rosa-Alcázar, A. I., Santiabáñez, C. y López-Pina, J. A. (2007).
Propiedades psicométricas de la escala para la detección de la ansiedad social (EDAS) en una muestra de adolescentes chilenos. International Journal of Clinical and Health Psychology, 7, 795-806 Wittchen, H. U., Stein, M. B. \& Kessler, R. C. (1999). Social fears and social phobia in a community sample of adolescents and young adults: Prevalence, risk factors and comorbility. Psychologycal Medicine, 29, 309-323. 